\title{
Reactivity of a nitrosyl ligand on dinuclear ruthenium hydrotris(pyrazolyl)borato complexes toward a NO molecule
}

\author{
Yasuhiro Arikawa,* Ayumi Ikeda, Naoki Matsumoto and Keisuke Umakoshi \\ Received (in $X X X, X X X) X$ th $X X X X X X X X X 20 X X$, Accepted $X$ th $X X X X X X X X X 20 X X$ \\ ${ }_{5}$ DOI: $10.1039 / b 000000 x$
}

A cationic mononitrosyl dinuclear ruthenium complex was prepared by removing one NO ligand of a dicationic dinitrosyl ruthenium complex using $\mathrm{NaN}_{3}$. Reduction and oxidation reactions of the mononitrosyl complex led to the isolation of a neutral nitrosyl-bridged complex and a dicationic mononitrosyl complex, respectively, as expected from the cyclic voltammogram. According to the

10 electron count, their reactions with a second NO molecule resulted in an $\mathrm{N}-\mathrm{N}$ coupling complex from the nitrosyl-bridged complex and the dicationic dinitrosyl complex from the dicationic mononitrosyl complex.

\section{Introduction}

The NO ligand on transition metal complexes has attracted a great deal of attention because of its "non-innocent" property 15 ( $\mathrm{M}-\mathrm{NO}^{+}$, linear form; $\mathrm{M}-\mathrm{NO}^{\circ}$ and $\mathrm{M}-\mathrm{NO}^{-}$, bent form). The transformations have been characterized by electrochemistry and IR, UV/Vis, and EPR spectroscopies, ${ }^{1}$ but most of the reported complexes are mononitrosyl mononuclear systems. We have found two neighboring NO ligands on a dinuclear ruthenium 20 complex $\left[\{\mathrm{TpRu}(\mathrm{NO})\}_{2}(\mu-\mathrm{Cl})(\mu-\mathrm{pz})\right]\left(\mathrm{BF}_{4}\right)_{2} \quad\left(\mathbf{1}:\left\{\mathrm{Ru}_{2}(\mathrm{NO})_{2}\right\}^{12}\right)^{2}$ $\left(\mathrm{Tp}=\mathrm{HB}(\text { pyrazol-1-yl })_{3}\right)$ and its unprecedented redox behaviour (eqn (1)). ${ }^{3}$ Reduction of the dicationic dinitrosyl ruthenium 1 induced an N-N bond formation of the two NO ligands, affording an $\mathrm{N}-\mathrm{N}$ coupling complex $\left[(\mathrm{TpRu})_{2}(\mu-\mathrm{Cl})\{\mu-\mathrm{N}(=\mathrm{O})-\mathrm{N}(=\mathrm{O})\}(\mu-\right.$ $25 \mathrm{pz})]\left(2:\left\{\mathrm{Ru}_{2}(\mathrm{NO})_{2}\right\}^{14}\right){ }^{3 \mathrm{a}}$ The reversibility of this $\mathrm{N}-\mathrm{N}$ bond was also observed. Treatment of $\mathbf{2}$ with protons gave an oxidobridged complex $\left[(\mathrm{TpRu})_{2}(\mu-\mathrm{Cl})(\mu-\mathrm{O})(\mu-\mathrm{pz})\right]$ (3), evolving $\mathrm{N}_{2} \mathrm{O}$. Double protonation of complex $\mathbf{3}$, followed by exposure to NO gas, reformed complex $\mathbf{1}$. These reactions indicate completion of 30 the $\mathrm{NO}$ reduction cycle $\left(2 \mathrm{NO}+2 \mathrm{H}^{+}+2 \mathrm{e}^{-}->\mathrm{N}_{2} \mathrm{O}+\mathrm{H}_{2} \mathrm{O}\right){ }^{3 \mathrm{~b}, \mathrm{c}}$ Although $\mathrm{NO}$ disproportionation ( $3 \mathrm{NO}->\mathrm{N}_{2} \mathrm{O}+\mathrm{NO}_{2}$ ) is a very common metal complex-mediated reaction, ${ }^{4}$ the reduction reaction of $\mathrm{NO}$ to $\mathrm{N}_{2} \mathrm{O}$ and $\mathrm{H}_{2} \mathrm{O}$ has been scarcely reported, ${ }^{3 c, 5}$ and is seen for metalloenzyme nitric oxide reductase (NOR). ${ }^{6}$

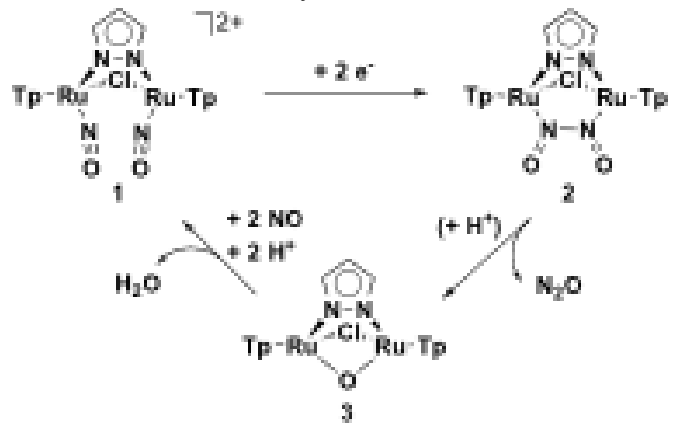

35 In this context, we are interested in the reactivity of a mononitrosyl ligand on dinuclear ruthenium complexes toward an additional NO molecule, including the formation of the unusual $\mathrm{N}-\mathrm{N}$ coupling complex 2 . For this purpose, at first a cationic mononitrosyl dinuclear ruthenium complex

$40[\{\mathrm{TpRu}(\mathrm{NO})\}\{\mathrm{TpRu}(\mathrm{NCMe})\}(\mu-\mathrm{Cl})(\mu-\mathrm{pz})]\left(\mathrm{BF}_{4}\right)$ $\left\{\mathrm{Ru}_{2}(\mathrm{NO})\right\}^{12}$ ) was synthesized by reaction of complex $\mathbf{1}$ with $\mathrm{NaN}_{3}$ as an NO removing reagent ${ }^{7}$ in $\mathrm{CH}_{3} \mathrm{CN}$. This reaction depended on the reaction solvents. The redox reactions are also described.

\section{${ }_{45}$ Results and Discussion}

The mononitrosyl complex $\mathbf{4}$ was prepared by treatment of $\mathbf{1}$ with nucleophile azide $\left(\mathrm{NaN}_{3}\right)$ in $\mathrm{CH}_{3} \mathrm{CN}$ to remove a $\mathrm{NO}$ ligand, followed by coordination of the solvent molecule (Scheme 1).
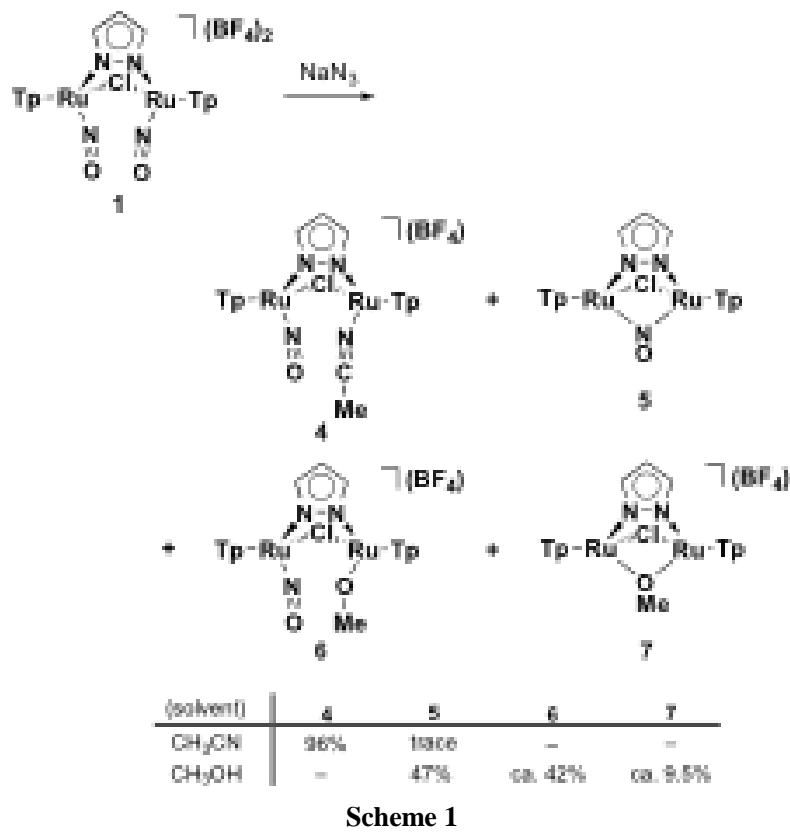


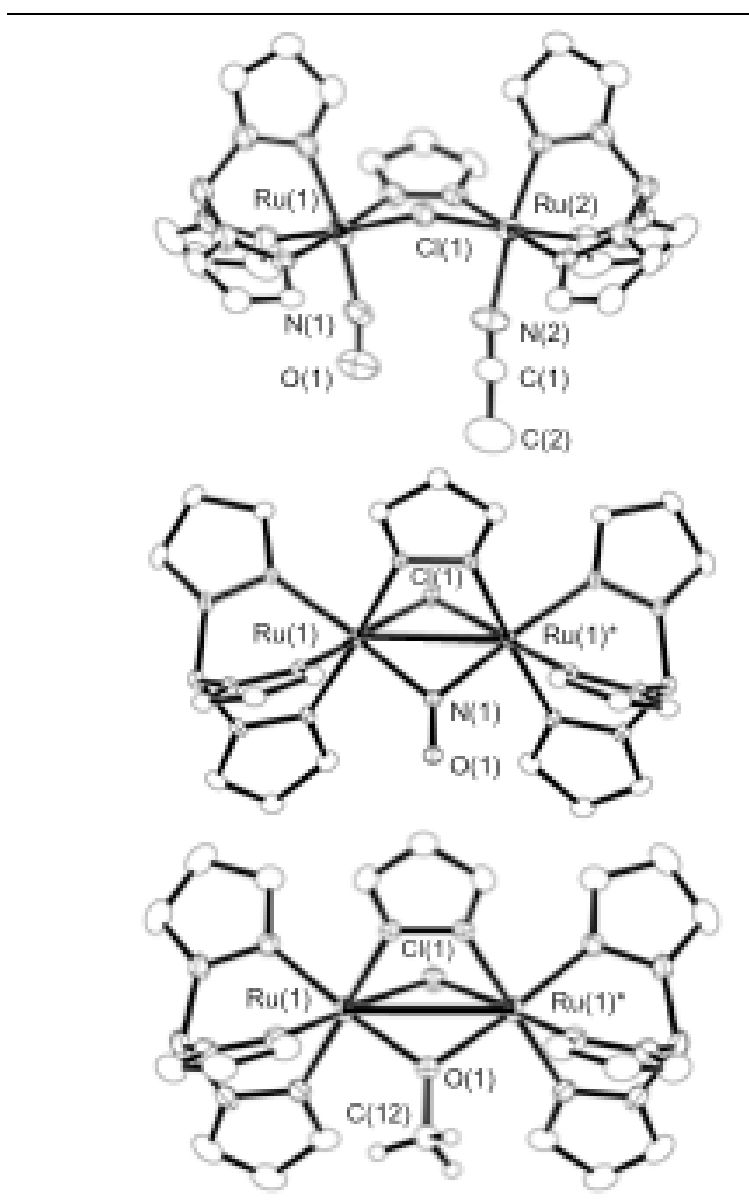

Fig. 1 Molecular structures of the cation part of $\mathbf{4}$ (top), 5 (middle), and the cation part of 7 (bottom) with thermal ellipsoids at the 50\% probability level. All hydrogen atoms except for O-Me (7) and solvent 5 molecules are omitted for clarity. Selected bond lengths $(\AA)$ and angles $\left({ }^{\circ}\right)$ for 4: $\mathrm{Ru}(1)-\mathrm{N}(1)=1.813(8), \mathrm{Ru}(2)-\mathrm{N}(2)=2.015(10), \mathrm{O}(1)-\mathrm{N}(1)=$ 1.145(12), N(2)-C(1) = 1.126(14), $\mathrm{Ru}(1)-\mathrm{N}(1)-\mathrm{O}(1)=166.1(9), \mathrm{Ru}(2)-$ $\mathrm{N}(2)-\mathrm{C}(1)=166.9(10)$. Selected bond lengths $(\AA)$ and angles $\left(^{\circ}\right)$ for $\mathbf{5}$ : $\mathrm{Ru}(1)-\mathrm{N}(1)=1.949(3), \mathrm{O}(1)-\mathrm{N}(1)=1.209(5), \mathrm{Ru}(1)-\mathrm{N}(1)-\mathrm{Ru}(1)^{*}=$ 10 96.38(15). Selected bond lengths $(\AA)$ and angles $\left({ }^{\circ}\right)$ for 7: $\mathrm{Ru}(1)-\mathrm{O}(1)=$ 1.992(3), O(1)-C(12) = 1.410(7), Ru(1)-O(1)-Ru(1)* = 104.97(18).

By column chromatography, complex 4 was isolated as a dark green solid in $96 \%$ yield, concomitant with a trace amount of a nitrosyl-bridged complex $\left[(\mathrm{TpRu})_{2}(\mu-\mathrm{Cl})(\mu-\mathrm{NO})(\mu-\mathrm{pz})\right] \quad$ (5:

$\left.15\left\{\mathrm{Ru}_{2}(\mathrm{NO})\right\}^{13}\right)$. But the use of $\mathrm{CH}_{3} \mathrm{OH}$ instead of $\mathrm{CH}_{3} \mathrm{CN}$ as the reaction solvent afforded complex 5 in $47 \%$ yield. In addition, two complexes, $[\{\mathrm{TpRu}(\mathrm{NO})\}\{\mathrm{TpRu}(\mathrm{OMe})\}(\mu-\mathrm{Cl})(\mu-\mathrm{pz})]\left(\mathrm{BF}_{4}\right)$ (6: $\left\{\mathrm{Ru}_{2}(\mathrm{NO})\right\}^{11} ;$ ca. $\left.42 \%\right)$ and $\left[(\mathrm{TpRu})_{2}(\mu-\mathrm{Cl})(\mu-\mathrm{OMe})(\mu-\right.$ $\mathrm{pz})]\left(\mathrm{BF}_{4}\right)$ (7) (ca. 9.5\%), were obtained. Complete purification 20 of $\mathbf{6}$ and $\mathbf{7}$ was hampered by the fact that they are inseparable mutual complexes. The $\mathrm{NO}$ elimination reaction in $\mathrm{CH}_{3} \mathrm{OH}$ is a complicated reaction, because the redox processes are required for the formation of 5, 6, and 7. Although the ${ }^{1} \mathrm{H}$ NMR spectra of 5 - 7 indicate paramagnetism, the ${ }^{1} \mathrm{H}$ NMR spectrum of $\mathbf{4}$ shows 25 diamagnetic signals assignable to distinct seven sets of peaks of the pyrazolyl groups (two Tp and one bridging pyrazolyl ligands), indicating an unsymmetrical dinuclear complex. The paramagnetic character of $\mathbf{7}$ indicates a weak antiferromagnetic coupling, as shown in a hydroxido-bridged dinuclear ruthenium 30 complex $\left.\left[(\mathrm{TpRu})_{2}(\mu-\mathrm{Cl})(\mu-\mathrm{OH})(\mu-\mathrm{pz})\right]\left(\mathrm{BF}_{4}\right)\right)^{3 \mathrm{~b}}$ The IR spectra of
4 and 6 exhibit $v(\mathrm{N \alpha O})$ bands $\left(4 ; 1883 \mathrm{~cm}^{-1}, \mathbf{6} ; 1898 \mathrm{~cm}^{-1}\right)$ which

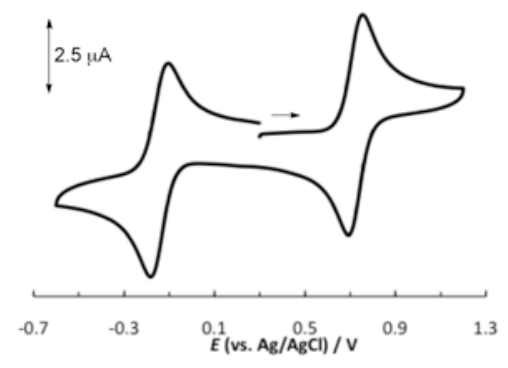

Fig. 2 Cyclic voltammogram of $4(0.1 \mathrm{mM})$ in $\mathrm{CH}_{3} \mathrm{CN}$ containing ${ }^{\mathrm{n}} \mathrm{Bu}_{4} \mathrm{NPF}_{6}(0.1 \mathrm{M})$; working electrode: Pt; counter electrode: Pt; reference: $35 \mathrm{Ag} / \mathrm{AgCl}$; scan rate $50 \mathrm{mVs}^{-1}$.

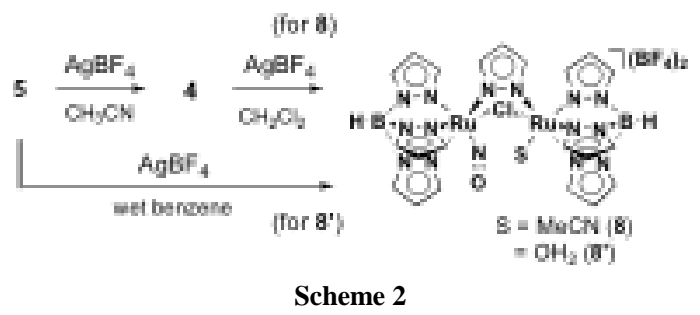

are lower frequencies than that of $1,^{3 a}$ together with a $v(\mathrm{C} \alpha \mathrm{N})$ band $\left(4 ; 2264 \mathrm{~cm}^{-1}\right)$. The FAB-MS spectra of 4 - 7 exhibit the 40 parent molecular ion signals, respectively.

The structures of $\mathbf{4 , 5}$, and $\mathbf{7}$ were confirmed by single-crystal X-ray diffraction analyses (Fig. 1). All three structures are dinuclear ruthenium complexes bridged by a chlorido and a pyrazolato ligand, but furthermore NO (for 5) or OMe (for 7) 45 bridges are seen. For complex 7, two NO ligands are removed. In complex 4, each ruthenium is coordinated by a NO and a MeCN ligand, respectively, exhibiting the unsymmetrical structure. The $\mathrm{N}-\mathrm{O}$ bond distance of 4 (1.145(12) $\AA$; terminal) is shorter than that of 5 (1.209(5) A; bridging), which is reasonable. 50 The order of the $\mathrm{Ru}-\mathrm{Ru}$ distances is 4 (3.7241(17) $\AA$ ) $>7$

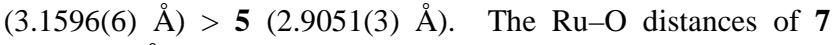
(1.992(3) $\AA$ ) are similar to those of the hydroxido-bridged complex $\left.\left[(\mathrm{TpRu})_{2}(\mu-\mathrm{Cl})(\mu-\mathrm{OH})(\mu-\mathrm{pz})\right]\left(\mathrm{BF}_{4}\right)(2.0038(19) \AA)\right)^{3 \mathrm{~b}}$

To check the redox behavior of $\mathbf{4}$, the cyclic voltammogram 55 was measured (Fig. 2). The CV of $\mathbf{4}$ features two reversible redox couple at $-0.150 \mathrm{~V}$ and $0.750 \mathrm{~V}\left(E_{1 / 2}\right.$ vs. Ag/AgCl). Reductive treatment of $\mathbf{4}$ with $\mathrm{KO}_{2}$ in $\mathrm{CH}_{2} \mathrm{Cl}_{2}$ gave the nitrosylbridged complex 5 in 61\% yield, releasing the MeCN ligand. Moreover, oxidation of 5 with $\mathrm{AgBF}_{4}$ in $\mathrm{CH}_{3} \mathrm{CN}$ reformed 4 in ${ }_{60} 94 \%$ yield (Scheme 2), showing the reversibility. On the other hand, oxidative treatment of $\mathbf{4}$ with $\mathrm{AgBF}_{4}$ in $\mathrm{CH}_{2} \mathrm{Cl}_{2}$ afforded a purple precipitate, followed by work-up to give a dicationic mononitrosyl dinuclear ruthenium complex $[\{\mathrm{TpRu}(\mathrm{NO})\}\{\mathrm{TpRu}(\mathrm{NCMe})\}(\mu-\mathrm{Cl})(\mu-\mathrm{pz})]\left(\mathrm{BF}_{4}\right)_{2}$ $\left.65\left\{\mathrm{Ru}_{2}(\mathrm{NO})\right\}^{11}\right)$ in $65 \%$ yield. In the IR spectrum of $\mathbf{8}$, a $v(\mathrm{N \alpha O})$ band $\left(1898 \mathrm{~cm}^{-1}\right)$ appears at higher frequency than that of $\mathbf{4}$, because of the oxidation reaction. The paramagnetic complex 8 was confirmed by the X-ray structural analysis of the $\mathrm{OH}_{2}$ ligated analog (complex 8'), where an $\mathrm{OH}_{2}$ ligand instead of the 70 acetonitrile ligand coordinated to the ruthenium atom. Complex 
8' was prepared by precipitation from reaction of the nitrosylbridged complex $\mathbf{5}$ with $\mathrm{AgBF}_{4}$ in wet benzene. However, when

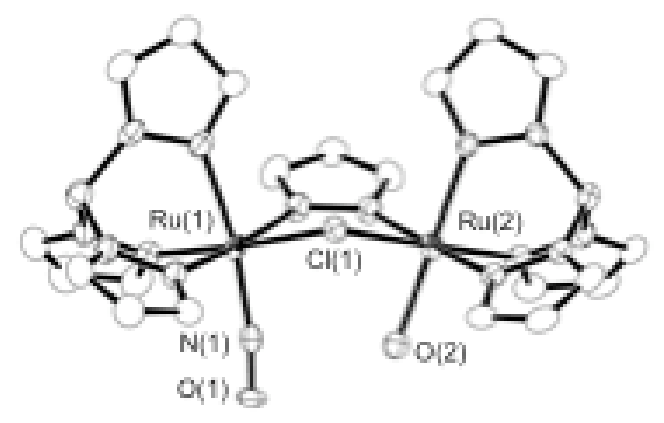

5 Fig. 3 Molecular structure of the cation part of $\mathbf{8}$ ' with thermal ellipsoids at the $50 \%$ probability level. Minor sets of the disordered atoms and all hydrogen atoms are omitted for clarity.
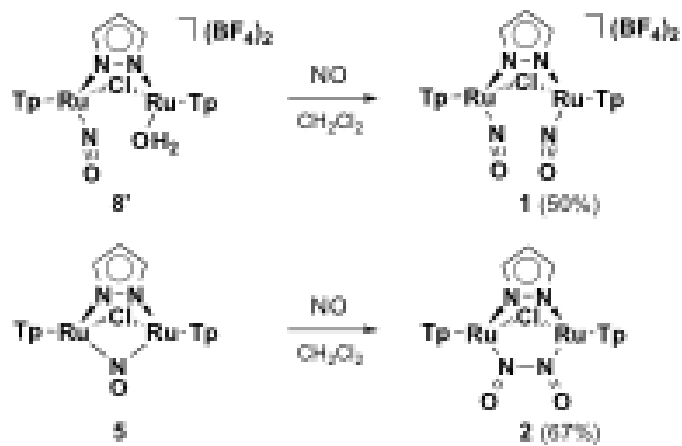

Scheme 3

10 this oxidation reaction was carried out in $\mathrm{CH}_{3} \mathrm{CN}$, only the $1 \mathrm{e}^{-}$ oxidation product 4 was isolated. The crystallographically determined structure of $\mathbf{8}$ ' is shown in Fig. 3. Unfortunately, the crystallographic disorder between $\mathrm{N \alpha O}$ and $\mathrm{OH}_{2}$ ligands causes uncertainty of the metric structural parameters, but the presence 15 of these two ligands was established.

With the desired mononitrosyl complexes in hand, their reactions to a second $\mathrm{NO}$ molecule were carried out (Scheme 3). Complex 8' $\left(\left\{\mathrm{Ru}_{2}(\mathrm{NO})\right\}^{11}\right)$ was reacted with $\mathrm{NO}$ (gas) for $3 \mathrm{~h}$ to give the dicationic dinitrosyl complex $\mathbf{1}\left(\left\{\mathrm{Ru}_{2}(\mathrm{NO})_{2}\right\}^{12}\right)$ as a red20 brown solid in $50 \%$ yield, where the $\mathrm{OH}_{2}$ ligand of 8 ' was replaced by a NO molecule. Treatment of the NO-bridged complex $5\left(\left\{\mathrm{Ru}_{2}(\mathrm{NO})\right\}^{13}\right)$ with $\mathrm{NO}$ (gas) for $3 \mathrm{~h}$ gave the $\mathrm{N}-\mathrm{N}$ coupling complex $2\left(\left\{\mathrm{Ru}_{2}(\mathrm{NO})_{2}\right\}^{14}\right)$ as a yellow-brown solid in $67 \%$ yield, which was purified by column chromatography. ${ }_{25}$ Although the reaction mechanism is unclear, transformation of the bridging $\mathrm{NO}$ ligand to the $\mathrm{N}-\mathrm{N}$ coupling form is interesting. In contrast to this, transformation of two NO molecules on dinuclear ruthenium complexes, affording trans-hyponitrite complexes, has been reported. ${ }^{8}$ On the other hand, reaction of the 30 cationic mononitrosyl ruthenium $\mathbf{4}\left(\left\{\mathrm{Ru}_{2}(\mathrm{NO})\right\}^{12}\right)$ with $\mathrm{NO}$ (gas) did not proceed sufficiently to recover the starting complex 4 (58\%), along with the formation of $\mathbf{1}(13 \%)$ and 2 (2.4\%) which should be formed after initial redox reaction of $\mathbf{4}$ with NO radical. The reactivity of $\mathbf{4}$ indicated that the reaction scheme $35\left(\left\{\mathrm{Ru}_{2}(\mathrm{NO})\right\}^{12}(\mathbf{4})+{ }^{-} \mathrm{NO}->\left\{\mathrm{Ru}_{2}(\mathrm{NO})_{2}\right\}^{13}\right)$ did not proceed, because the $\mathrm{CV}$ of 2 showed a reversible two-electron redox couple $\left(\left(2:\left\{\mathrm{Ru}_{2}(\mathrm{NO})_{2}\right\}^{14}\right) /\left(\mathbf{1}:\left\{\mathrm{Ru}_{2}(\mathrm{NO})_{2}\right\}^{12}\right)\right)$ at $0.389 \mathrm{~V}\left(E_{1 / 2} v s\right.$. $\mathrm{Ag} / \mathrm{AgCl}),{ }^{3 \mathrm{a}}$ indicating that the putative dinitrosyl complex $\left\{\mathrm{Ru}_{2}(\mathrm{NO})_{2}\right\}^{13}$ is unstable. In addition, the difficulty in 40 substituting the MeCN ligand of $\mathbf{4}$ may account for this low reactivity.

\section{Conclusions}

In conclusion, we succeeded in isolating the neutral nitrosylbridged complex and the cationic and dicationic mononitrosyl 45 complexes, and showed their interconversion by chemical redox reactions. As expected from the electron count, the reactions of the nitrosyl-bridged complex $\mathbf{5}\left(\left\{\mathrm{Ru}_{2}(\mathrm{NO})\right\}^{13}\right)$ and the dicationic mononitrosyl complex 8' $\left(\left\{\mathrm{Ru}_{2}(\mathrm{NO})\right\}^{11}\right)$ with a second $\mathrm{NO}$ molecule resulted in the $\mathrm{N}-\mathrm{N}$ coupling complex $2\left(\left\{\mathrm{Ru}_{2}(\mathrm{NO})_{2}\right\}^{14}\right)$ 50 and the dicationic dinitrosyl complex $1 \quad\left(\left\{\mathrm{Ru}_{2}(\mathrm{NO})_{2}\right\}^{12}\right)$, respectively. On the other hand, the NO addition reaction of the cationic mononitrosyl complex $\mathbf{4}\left(\left\{\mathrm{Ru}_{2}(\mathrm{NO})\right\}^{12}\right)$ did not proceed.

\section{Experimental}

\section{General}

55 All reactions were carried out under $\mathrm{N}_{2}$ or Ar unless otherwise noted and subsequent work-up manipulations were performed in air. The starting material $\left[\{\mathrm{TpRu}(\mathrm{NO})\}_{2}(\mu-\mathrm{Cl})(\mu-\mathrm{pz})\right]\left(\mathrm{BF}_{4}\right)_{2}(\mathbf{1})$ was prepared according to a previously reported method. ${ }^{3 a}$ Organic solvents and all other reagents were commercially 60 available and used without further purification. NMR spectra were recorded on a Varian Gemini-300 and a JEOL JNM-AL-400 spectrometers. ${ }^{1} \mathrm{H}$ NMR chemical shifts in $\mathrm{CDCl}_{3}$ or $\mathrm{CD}_{3} \mathrm{CN}$ are quoted with respect to TMS and the deuterated solvent signal, respectively, and ${ }^{13} \mathrm{C}\left\{{ }^{1} \mathrm{H}\right\}$ NMR chemical shifts are quoted with 65 respect to the deuterated solvent signal. Infrared spectra in $\mathrm{KBr}$ pellets were obtained on JASCO FT-IR-4100 spectrometers. Fast atom bombardment mass spectra (FAB-MS) was recorded on a JEOL JMS-700N spectrometer. Elemental analyses $(\mathrm{C}, \mathrm{H}, \mathrm{N})$ were performed on a Perkin Elmer 2400II elemental analyzer.

70

\section{Reactions of $\left[\{\mathrm{TpRu}(\mathrm{NO})\}_{2}(\mu-\mathrm{Cl})(\mu-\mathrm{pz})\right]\left(\mathrm{BF}_{4}\right)_{2}(1)$ with $\mathrm{NaN}_{3}$}

$\mathrm{NaN}_{3}$ (5.1 mg, $0.078 \mathrm{mmol}$ ) was added to a solution of complex 1 (50.0 mg, $0.0518 \mathrm{mmol}$ ) in $\mathrm{CH}_{3} \mathrm{CN}$ (10 mL), followed by stirring for $3 \mathrm{~h}$ at room temperature. After evaporation to dryness, the 75 residue was separated on column chromatography with a silica gel using a $\mathrm{CH}_{2} \mathrm{Cl}_{2}$ eluent to give $\left[(\mathrm{TpRu})_{2}(\mu-\mathrm{Cl})(\mu-\mathrm{NO})(\mu-\mathrm{pz})\right]$ (5) as an ocher solid (trace) and a $\mathrm{CH}_{2} \mathrm{Cl}_{2}$-acetone (10/1) eluent to give $[\{\mathrm{TpRu}(\mathrm{NO})\}\{\mathrm{TpRu}(\mathrm{NCMe})\}(\mu-\mathrm{Cl})(\mu-\mathrm{pz})]\left(\mathrm{BF}_{4}\right)$ (4) as a dark green solid (44.2 mg, 96\%).

80 When this reaction was performed in a $\mathrm{CH}_{3} \mathrm{OH}$ reaction solvent (10 mL) using complex 1 (30.0 mg, $0.031 \mathrm{mmol})$ and $\mathrm{NaN}_{3} \quad$ (6.1 mg, $\left.0.094 \mathrm{mmol}\right)$, column chromatographic purification with a silica gel afforded complex 5 (11.1 mg, 47\%; a $\mathrm{CH}_{2} \mathrm{Cl}_{2}$ eluent), [(TpRu $\left.)_{2}(\mu-\mathrm{Cl})(\mu-\mathrm{OMe})(\mu-\mathrm{pz})\right]\left(\mathrm{BF}_{4}\right)(7)$ as a ${ }_{85}$ green solid (2.5 mg, ca. 9.5\%; a $\mathrm{CH}_{2} \mathrm{Cl}_{2}$-acetone (20/1) eluent), and $[\{\mathrm{TpRu}(\mathrm{NO})\}\{\mathrm{TpRu}(\mathrm{OMe})\}(\mu-\mathrm{Cl})(\mu-\mathrm{pz})]\left(\mathrm{BF}_{4}\right) \quad$ (6) as a brown solid (11.4 mg, ca. 42\%; a $\mathrm{CH}_{2} \mathrm{Cl}_{2}$-acetone (10/1) eluent). Complete purification of $\mathbf{6}$ and $\mathbf{7}$ was hampered by the fact that they are inseparable mutual complexes.

90 4: IR (KBr, pellet): v(BH) $2520(\mathrm{w}) ; v(\mathrm{C} \equiv \mathrm{N}) 2264(\mathrm{w}) ; \mathrm{v}(\mathrm{N} \equiv \mathrm{O})$ 
1883 (s); v(BF) 1113-1053 (s) $\mathrm{cm}^{-1} .{ }^{1} \mathrm{H}$ NMR $\left(\mathrm{CDCl}_{3}\right): \delta 8.43$ (d, $J=2.2 \mathrm{~Hz}, 1 \mathrm{H}, \mathrm{pz}), 8.14$ (d, $J=1.8 \mathrm{~Hz}, 1 \mathrm{H}, \mathrm{pz}), 8.08$ (d, $J=2.2$ $\mathrm{Hz}, 1 \mathrm{H}, \mathrm{pz}$ ), 7.97 (d, $J=2.4 \mathrm{~Hz}, 1 \mathrm{H}, \mathrm{pz}), 7.87$ (d, $J=2.4 \mathrm{~Hz}, 1 \mathrm{H}$, pz), 7.81 (d, $J=2.4 \mathrm{~Hz}, 1 \mathrm{H}, \mathrm{pz}), 7.78$ (d, $J=2.3 \mathrm{~Hz}, 1 \mathrm{H}, \mathrm{pz})$, 7.77 (d, $J=2.4 \mathrm{~Hz}, 1 \mathrm{H}, \mathrm{pz}$ ), 7.75 (d, $J=2.3 \mathrm{~Hz}, 1 \mathrm{H}, \mathrm{pz}), 7.60$ (d, $J=1.8 \mathrm{~Hz}, 1 \mathrm{H}, \mathrm{pz}), 7.15$ (d, $J=2.0 \mathrm{~Hz}, 1 \mathrm{H}, \mathrm{pz}), 7.03$ (d, $J=2.4$ $\mathrm{Hz}, 1 \mathrm{H}, \mathrm{pz}), 6.91$ (d, $J=2.2 \mathrm{~Hz}, 1 \mathrm{H}, \mathrm{pz}), 6.85$ (d, $J=1.7 \mathrm{~Hz}, 1 \mathrm{H}$, pz), 6.63 (t, $J=2.4 \mathrm{~Hz}, 1 \mathrm{H}, \mathrm{pz}), 6.51$ (t, $J=2.4 \mathrm{~Hz}, 1 \mathrm{H}, \mathrm{pz}), 6.35$ (t, $J=2.3 \mathrm{~Hz}, 1 \mathrm{H}, \mathrm{pz}), 6.34(\mathrm{t}, J=2.3 \mathrm{~Hz}, 1 \mathrm{H}, \mathrm{pz}), 6.24(\mathrm{t}, J=2.3$ $10 \mathrm{~Hz}, 1 \mathrm{H}, \mathrm{pz}), 6.23$ (t, $J=2.3 \mathrm{~Hz}, 1 \mathrm{H}, \mathrm{pz}), 6.15$ (t, $J=2.2 \mathrm{~Hz}, 1 \mathrm{H}$, pz), 2.44 (s, 3H, CH $\mathrm{CH}_{3} \mathrm{CN} .{ }^{13} \mathrm{C}\left\{{ }^{1} \mathrm{H}\right\}$ NMR $\left(\mathrm{CD}_{3} \mathrm{CN}\right): \delta 145.6(\mathrm{pz})$, 145.2 (pz), 145.1 (pz), 144.9 (pz), 144.8 (pz), 144.6 (pz), 143.9 (pz), 143.2 (pz), 139.7 (pz), 139.2 (pz), 138.3 (pz) 137.6 (pz), 137.4 (pz), 137.1 (pz), 110.2 (pz), 109.4 (pz), 108.6 (pz), 108.2 15 (pz), 108.1 (pz), 107.4 (pz), $107.3(\mathrm{pz}), 126.3\left(\mathrm{CH}_{3} \mathrm{CN}\right), 5.23$ $\left(\mathrm{CH}_{3} \mathrm{CN}\right)$. FAB-MS $(\mathrm{m} / \mathrm{z}): 802.2\left([\mathrm{M}]^{+}\right), \quad 761.2 \quad([\mathrm{M}-$ $\left.\left.\left(\mathrm{CH}_{3} \mathrm{CN}\right)\right]^{+}\right)$. Elemental analysis (\%) calcd for $\mathrm{C}_{23} \mathrm{H}_{26} \mathrm{~N}_{16} \mathrm{~B}_{3} \mathrm{ClF}_{4} \mathrm{ORu}_{2}$ : C 31.09, H 2.95, N 25.22; found: C 30.91, H 2.76, N 24.95.

20 5: IR (KBr, pellet): $v(\mathrm{BH}) 2485(\mathrm{w}) \mathrm{cm}^{-1}$. FAB-MS (m/z): 761.1 $\left([\mathrm{M}]^{+}\right), 694.0\left([\mathrm{M}-\mathrm{pz}]^{+}\right), 528.2\left(\left[\mathrm{Tp}_{2} \mathrm{Ru}\right]^{+}\right)$. Elemental analysis (\%) calcd for $\mathrm{C}_{21} \mathrm{H}_{23} \mathrm{~N}_{15} \mathrm{~B}_{2} \mathrm{ClORu}_{2}$ : C 33.16, H 3.05, N 27.62; found: C 33.62, H 2.86, N 27.24.

6: IR (KBr, pellet): v(BH) $2518(\mathrm{w}) ; \mathrm{v}(\mathrm{N} \equiv \mathrm{O}) 1898$ (s); v(BF) 25 1120-1052 (s) cm $\mathrm{cm}^{-1}$. FAB-MS (m/z): $792.0\left([\mathrm{M}]^{+}\right), 762.0([\mathrm{M}-$ $\left.(\mathrm{NO})]^{+}\right)$.

7: IR (KBr, pellet): v(BH) 2514 (w); v(BF) 1120-1050 (s) $\mathrm{cm}^{-1}$. FAB-MS $(\mathrm{m} / \mathrm{z}): 762.0\left([\mathrm{M}]^{+}\right)$.

\section{${ }_{30}$ Redox reactions of $[\{\mathrm{TpRu}(\mathrm{NO})\}\{\mathrm{TpRu}(\mathrm{NCMe})\}(\mu-\mathrm{Cl})(\mu-$ $\mathrm{pz})]\left(\mathrm{BF}_{4}\right)(4)$ and $\left[(\mathrm{TpRu})_{2}(\mu-\mathrm{Cl})(\mu-\mathrm{NO})(\mu-\mathrm{pz})\right](5)$}

$\mathrm{KO}_{2}(7.7 \mathrm{mg}, 0.11 \mathrm{mmol})$ was added to a solution of complex 4 (92.2 mg, $0.104 \mathrm{mmol})$ in $\mathrm{CH}_{2} \mathrm{Cl}_{2}(10 \mathrm{~mL})$, and the mixture was stirred for $17 \mathrm{~h}$ at room temperature. After addition of $\mathrm{KO}_{2}$ (7.6 $35 \mathrm{mg}, 0.11 \mathrm{mmol}$ ) and stirring for a further $7 \mathrm{~h}$, column chromatographic purification with a silica gel afforded complex 5 (48.4 mg, 61\%) using a $\mathrm{CH}_{2} \mathrm{Cl}_{2}$ eluent.

To a $\mathrm{CH}_{2} \mathrm{Cl}_{2}(10 \mathrm{~mL})$ solution of complex 4 (50.0 mg, 0.0563 mmol) was added $\mathrm{AgBF}_{4}(11.0 \mathrm{mg}, 0.0565 \mathrm{mmol})$ in benzene $40(1.0 \mathrm{~mL})$. After the mixture was stirred overnight and evaporated to dryness, the residue was extracted with acetone, followed by filtration. After evaporation, the residue was washed with benzene and a small amount of $\mathrm{CH}_{2} \mathrm{Cl}_{2}$ to give $[\{\mathrm{TpRu}(\mathrm{NO})\}\{\mathrm{TpRu}(\mathrm{NCMe})\}(\mu-\mathrm{Cl})(\mu-\mathrm{pz})]\left(\mathrm{BF}_{4}\right)_{2}(\mathbf{8})$ as a purple 45 solid (35.9 mg, 65\%).

To a $\mathrm{CH}_{3} \mathrm{CN}$ (10 mL) solution of complex 5 (25.0 mg, 0.0329 mmol) was added $\mathrm{AgBF}_{4}(6.4 \mathrm{mg}, 0.033 \mathrm{mmol}$ ). After the mixture was stirred overnight and evaporated to dryness, the residue was separated by column chromatography with a silica 50 gel using a $\mathrm{CH}_{2} \mathrm{Cl}_{2}$-acetone (10/1) eluent to give complex 4 (27.5 mg, 94\%). On the other hand, the use of a wet benzene reaction solvent (5.0 mL), complex 5 (25.0 mg, $0.0329 \mathrm{mmol}$ ), and $\mathrm{AgBF}_{4}$ (12.8 $\mathrm{mg}, 0.0658 \mathrm{mmol}$ ) resulted in a dark red purple precipitate. After stirring for $4 \mathrm{~h}$ and decantation of the mixture, the 55 precipitate was washed several times with benzene to yield $\left[\{\mathrm{TpRu}(\mathrm{NO})\}\left\{\mathrm{TpRu}\left(\mathrm{OH}_{2}\right)\right\}(\mu-\mathrm{Cl})(\mu-\mathrm{pz})\right]\left(\mathrm{BF}_{4}\right)_{2} \quad\left(\mathbf{8}^{\prime}\right)$ as a redpurple solid (29.3 mg, 94\%).
8: IR (KBr, pellet): $v(\mathrm{BH}) 2523(\mathrm{w}) ; v(\mathrm{~N} \equiv \mathrm{O}) 1898$ (s); $v(\mathrm{BF})$ 1121-1053 (s) $\mathrm{cm}^{-1}$. FAB-MS (m/z): $802.2\left([\mathrm{M}]^{+}\right), 761.1([\mathrm{M}-$ $\left.\left.60\left(\mathrm{CH}_{3} \mathrm{CN}\right)\right]^{+}\right)$. Elemental analysis (\%) calcd for $\mathrm{C}_{23} \mathrm{H}_{26} \mathrm{~N}_{16} \mathrm{~B}_{4} \mathrm{ClF}_{8} \mathrm{ORu}_{2}$ : C 28.32, $\mathrm{H}$ 2.69, $\mathrm{N}$ 22.98; found: $\mathrm{C} 28.55$, H 2.90, N 23.04.

8': IR (KBr, pellet): v(BH) $2543(\mathrm{w}) ; \mathrm{v}(\mathrm{N} \equiv \mathrm{O}) 1915$ (s); v(BF) 1122-1053 (s) $\mathrm{cm}^{-1}$. FAB-MS $(\mathrm{m} / \mathrm{z}): 778\left([\mathrm{M}-1]^{+}\right), 761.1([\mathrm{M}-$ $\left.\left.65\left(\mathrm{OH}_{2}\right)\right]^{+}\right), 694.0\left(\left[\mathrm{M}-\left(\mathrm{OH}_{2}\right)-\mathrm{pz}\right]^{+}\right)$. Elemental analysis (\%) calcd for $\mathrm{C}_{24} \mathrm{H}_{31} \mathrm{~N}_{15} \mathrm{~B}_{4} \mathrm{Cl}_{7} \mathrm{~F}_{8} \mathrm{O}_{2} \mathrm{Ru}_{2}$ : C 23.88, H 2.59, N 17.40; found: C 24.04, H 2.27, N 17.87.

Reactivities of $[\{\mathrm{TpRu}(\mathrm{NO})\}\{\mathrm{TpRu}(\mathrm{NCMe})\}(\mu-\mathrm{Cl})(\mu-$ pz) $]\left(\mathrm{BF}_{4}\right) \quad(4), \quad\left[(\mathrm{TpRu})_{2}(\mu-\mathrm{Cl})(\mu-\mathrm{NO})(\mu-\mathrm{pz})\right] \quad(5), \quad$ and ${ }_{70}\left[\{\mathrm{TpRu}(\mathrm{NO})\}\left\{\mathrm{TpRu}\left(\mathrm{OH}_{2}\right)\right\}(\mu-\mathrm{Cl})(\mu-\mathrm{pz})\right]\left(\mathrm{BF}_{4}\right)_{2} \quad\left(8^{\prime}\right)$ toward NO gas

In a Schlenk flask, complex 8' (32.0 mg, $0.0336 \mathrm{mmol}$ ) was dissolved in distilled $\mathrm{CH}_{2} \mathrm{Cl}_{2}(10 \mathrm{~mL})$, followed by freeze-pumpthaw cycling for three times. After the cycling, NO gas was 75 introduced into the Schlenk flask through a column containing $\mathrm{KOH}$ pellets and through an acetone/liquid $\mathrm{N}_{2}\left(-78{ }^{\circ} \mathrm{C}\right)$ cooled trap to remove impurities. The solution was exposed to NO gas for $3 \mathrm{~h}$ and evaporated to dryness, followed by washing with $\mathrm{CH}_{2} \mathrm{Cl}_{2}$. The resulting red-brown powder was crystallized from ${ }_{80} \mathrm{CH}_{3} \mathrm{CN} /$ ether to afford $\left[\{\mathrm{TpRu}(\mathrm{NO})\}_{2}(\mu-\mathrm{Cl})(\mu-\mathrm{pz})\right]\left(\mathrm{BF}_{4}\right)_{2} \quad$ (1) (16.2 mg, 50\%).

Following analogous procedures to those above, reaction of complex 5 (30.7 mg, $0.0404 \mathrm{mmol})$ with $\mathrm{NO}$ gas in distilled $\mathrm{CH}_{2} \mathrm{Cl}_{2}(10 \mathrm{~mL})$ afforded $\left[(\mathrm{TpRu})_{2}(\mu-\mathrm{Cl})\{\mu-\mathrm{N}(=\mathrm{O})-\mathrm{N}(=\mathrm{O})\}(\mu-\right.$ ${ }_{85} \mathrm{pz}$ )] (2) (21.5 mg, 67\%), which was purified by column chromatography.

A solution of complex 4 (41.0 mg, $0.0461 \mathrm{mmol})$ in distilled $\mathrm{CH}_{2} \mathrm{Cl}_{2}(10 \mathrm{~mL})$ was exposed to $\mathrm{NO}$ gas according to the method described above. After filtration, column chromatographic 90 purification with a silica gel gave unreacted complex 4 (23.7 mg, $58 \%$ ), complex 1 (6.0 mg, 13\%), and complex 2 (0.9 mg, 2.4\%).

\section{Single-crystal X-ray structural determinations}

The crystallographic data are summarized in Table 1 . X-ray 95 quality single crystals were obtained from THF/ether (for 4. $\left(\mathrm{C}_{4} \mathrm{H}_{8} \mathrm{O}\right)_{3}$ ), $\quad \mathrm{CH}_{3} \mathrm{CHCl}_{2} / \mathrm{MeOH}$ (for 5. $(\mathrm{MeOH})_{1.33} \cdot\left(\mathrm{CH}_{3} \mathrm{CHCl}_{2}\right)_{0.33}$ ), $\quad \mathrm{CH}_{2} \mathrm{ClCH}_{2} \mathrm{Cl} /$ ether (for 7· $\left(\mathrm{CH}_{2} \mathrm{ClCH}_{2} \mathrm{Cl}\right)$ ), and $\mathrm{CH}_{2} \mathrm{Cl}_{2} /$ hexane (for $\left.\mathbf{8} \cdot\left(\mathrm{CH}_{2} \mathrm{Cl}_{2}\right)_{3}\right)$, respectively. Diffraction data were collected at $-180{ }^{\circ} \mathrm{C}$ under a 100 stream of cold dinitrogen gas on a Rigaku RA-Micro7 HFM instrument equipped with a Rigaku Saturn724+ CCD detector by using graphite-monochromated Mo K $\alpha$ radiation. The intensity images were obtained at exposure of $8 \mathrm{~s} /{ }^{\circ}\left(4 \cdot\left(\mathrm{C}_{4} \mathrm{H}_{8} \mathrm{O}\right)_{3}\right.$ and 7· $\left.\left(\mathrm{CH}_{2} \mathrm{ClCH}_{2} \mathrm{Cl}\right)\right), 16 \mathrm{~s} /{ }^{\circ}\left(\mathbf{5} \cdot(\mathrm{MeOH})_{1.33} \cdot\left(\mathrm{CH}_{3} \mathrm{CHCl}_{2}\right)_{0.33}\right)$, and 4 $105 \mathrm{~S} /{ }^{\circ}\left(\mathbf{8}^{\prime} \cdot\left(\mathrm{CH}_{2} \mathrm{Cl}_{2}\right)_{3}\right)$. The frame data were integrated using a Rigaku CrystalClear program package, and the data sets were corrected for absorption using REQAB program.

The calculations were performed with a CrystalStructure software package. The structures were solved by direct methods 110 (for $\mathbf{5} \cdot(\mathrm{MeOH})_{1.33} \cdot\left(\mathrm{CH}_{3} \mathrm{CHCl}_{2}\right)_{0.33}, \quad \mathbf{7} \cdot\left(\mathrm{CH}_{2} \mathrm{ClCH}_{2} \mathrm{Cl}\right)$, and 8' $\left.\left(\mathrm{CH}_{2} \mathrm{Cl}_{2}\right)_{3}\right)$ and Patterson methods (for $\left.\mathbf{4} \cdot\left(\mathrm{C}_{4} \mathrm{H}_{8} \mathrm{O}\right)_{3}\right)$, and refined on $F^{2}$ by the full-matrix least squares methods. Anisotropic refinement was applied to all non-hydrogen atoms except for three THF crystal solvents and a $\mathrm{BF}_{4}$ group in 
4. $\left(\mathrm{C}_{4} \mathrm{H}_{8} \mathrm{O}\right)_{3}$, and the disordered minor positions (NO and $\mathrm{O}$ atoms) and fluorine atoms of two $\mathrm{BF}_{4}$ groups in $\mathbf{8}^{\prime} \cdot\left(\mathrm{CH}_{2} \mathrm{Cl}_{2}\right)_{3}$. For $\mathbf{4} \cdot\left(\mathrm{C}_{4} \mathrm{H}_{8} \mathrm{O}\right)_{3}$, three fluorine atoms of a $\mathrm{BF}_{4}$ group were

Table 1 Crystallographic data for $\mathbf{4} \cdot\left(\mathrm{C}_{4} \mathrm{H}_{8} \mathrm{O}\right)_{3}, \mathbf{5} \cdot(\mathrm{MeOH})_{1.33} \cdot\left(\mathrm{CH}_{3} \mathrm{CHCl}_{2}\right)_{0.33}, \mathbf{7} \cdot\left(\mathrm{CH}_{2} \mathrm{ClCH}_{2} \mathrm{Cl}\right)$, and $\mathbf{8} \cdot\left(\mathrm{CH}_{2} \mathrm{Cl}_{2}\right)_{3}$

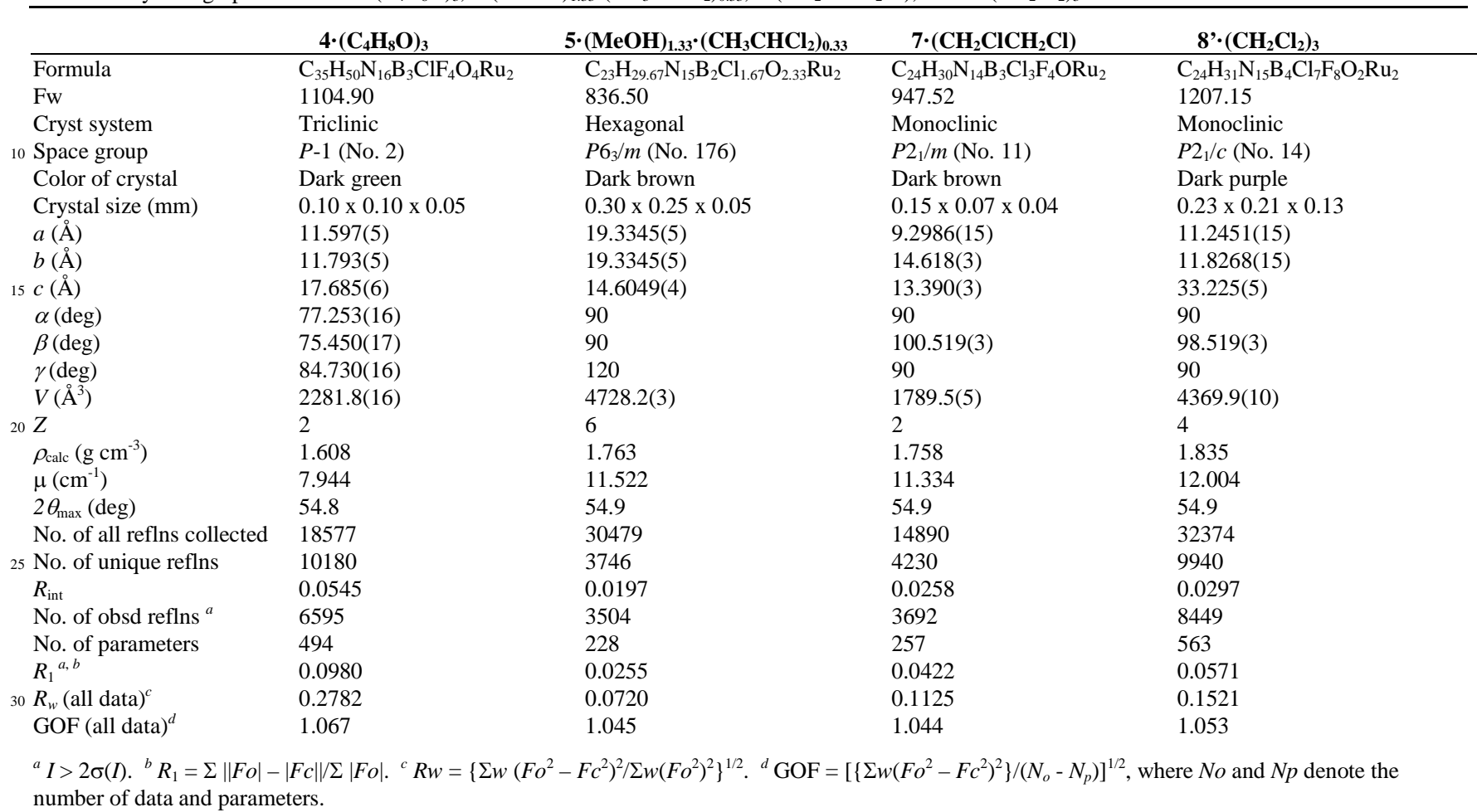

applied to $\mathrm{BF}_{4}$ and three THF atoms. For

35 5. $(\mathrm{MeOH})_{1.33} \cdot\left(\mathrm{CH}_{3} \mathrm{CHCl}_{2}\right)_{0.33}$, one $\mathrm{MeOH}$, one-third $\mathrm{MeOH}$, and one-third $\mathrm{CH}_{3} \mathrm{CHCl}_{2}$ crystal solvents are included. The latter two are located in the special positions, where the oxygen atom of the $\mathrm{MeOH}$ crystal solvent is disordered over three positions and for $\mathrm{CH}_{3} \mathrm{CHCl}_{2}$ crystal solvent the carbon and chlorine atoms are 40 disordered over two and three positions, respectively. Three protons of the OMe group and the $\mathrm{CH}_{2} \mathrm{ClCH}_{2} \mathrm{Cl}$ crystal solvent in 7. $\left(\mathrm{CH}_{2} \mathrm{ClCH}_{2} \mathrm{Cl}\right)$ are disordered over two positions with an occupancy factor of $50: 50$. For $\mathbf{8}^{\prime} \cdot\left(\mathrm{CH}_{2} \mathrm{Cl}_{2}\right)_{3}$, there was a disorder between $\mathrm{N} \equiv \mathrm{O}$ group and $\mathrm{O}\left(\mathrm{OH}_{2}\right)$ atom with an

45 occupancy factor of $0.7 / 0.3$. Moreover, three fluorine atoms on each of the two $\mathrm{BF}_{4}$ groups were disordered with an occupancy factor of 0.7/0.3. Restraints were applied to two $\mathrm{BF}_{4}$ and three $\mathrm{CH}_{2} \mathrm{Cl}_{2}$ atoms in $\mathbf{8}^{\prime} \cdot\left(\mathrm{CH}_{2} \mathrm{Cl}_{2}\right)_{3}$. Hydrogen atoms for all structures were put at calculated positions, except for B-H $\left(\mathbf{8}^{\prime} \cdot\left(\mathrm{CH}_{2} \mathrm{Cl}_{2}\right)_{3}\right)$, 50 while those of the $\mathrm{OH}_{2}$ ligand $\left(\mathbf{8}^{\prime} \cdot\left(\mathrm{CH}_{2} \mathrm{Cl}_{2}\right)_{3}\right)$ and the crystal solvent molecules $\left(\mathbf{4} \cdot\left(\mathrm{C}_{4} \mathrm{H}_{8} \mathrm{O}\right)_{3}, \mathbf{5} \cdot(\mathrm{MeOH})_{1.33} \cdot\left(\mathrm{CH}_{3} \mathrm{CHCl}_{2}\right)_{0.33}\right.$, and $\left.7 \cdot\left(\mathrm{CH}_{2} \mathrm{ClCH}_{2} \mathrm{Cl}\right)\right)$ were not included in the calculations.

\section{Acknowledgements}

This work was supported by JSPS KAKENHI grant number ${ }_{55} 22685008$ and by a Grant-in-Aid for Scientific Research from Nagasaki University.

\section{Notes and references}

Division of Chemistry and Materials Science, Graduate School of 60 Engineering, Nagasaki University, Bunkyo-machi 1-14, Nagasaki 8528521, Japan. Fax: +81-95-819-2684; E-mail: arikawa@nagasaki-u.ac.jp $\dagger$ CCDC 939832-939835. For crystallographic data in CIF or other electronic format see DOI: 10.1039/c3dt51319j

651 (a) G. K. Lahiri and K. Wolfgang, Dalton Trans., 2010, 39, 44714478; (b) F. Roncaroli, M. Videla, L. D. Slep and J. A. Olabe, Coord. Chem. Rev., 2007, 251, 1903-1930; (c) S. Sarkar, B. Sarkar, N. Chanda, S. Kar, S. M. Mobin, J. Fiedler, W. Kaim and G. K. Lahiri, Inorg. Chem., 2005, 44, 6092-6099; (d) J. A. McCleverty, Chem.

70 Rev., 2004, 104, 403-418; (e) R. G. Serres, C. A. Grapperhaus, E. Bothe, E. Bill, T. Weyhermüller, F. Neese and K. Wieghardt, J. Am. Chem. Soc., 2004, 126, 5138-5153.

2 To grasp the redox states better, the modified notation $\left\{\mathrm{M}_{2}(\mathrm{NO})_{\mathrm{x}}\right\}^{n}$ based on the Enemark-Feltham electron counting formalism is

75 described, where $n$ denotes the number of electrons in the two metal $\mathrm{d}$ and $\pi^{*}{ }_{\text {No }}$ orbitals (or $n$ represents the number of $d$ electrons on the two metals when the $\mathrm{NO}$ is formally considered to be $\mathrm{NO}^{+}$).

3 (a) Y. Arikawa, T. Asayama, Y. Moriguchi, S. Agari and M. Onishi, J. Am. Chem. Soc., 2007, 129, 14160-14161; (b) Y. Arikawa, N.

$80 \quad$ Matsumoto, T. Asayama, K. Umakoshi and M. Onishi, Dalton Trans., 2011, 40, 2148-2150; (c) Y. Arikawa and M. Onishi, Coord. Chem. Rev., 2012, 256, 468-478.

4 (a) G. B. Richter-Addo and P. Legzdins, Metal Nitrosyls, Oxford University Press, New York, 1992; (b) P. C. Ford and I. M. Lorkovic, Chem. Rev., 2002, 102, 993-1017; (c) T. W. Hayton, P. Legzdins and W. B. Sharp, Chem. Rev., 2002, 102, 935-991; (d) W. B. Tolman, Activation of Small Molecules, Wiley-VCH, Weinheim, 2006.

5 S. Zheng, T. C. Berto, E. W. Dahl, M. B. Hoffman, A. L. Speelman 90 and N. Lehnert, J. Am. Chem. Soc., 2013, 135, 4902-4905.

6 (a) I. M. Wasser, S. de Vries, P. Moënne-Loccoz, I. Schröder and K. D. Karlin, Chem. Rev., 2002, 102, 1201-1234; (b) B. A. Averill, Chem. Rev., 1996, 96, 2951-2964; (c) P. Girsch and S. de Vries, 
Biochim. Biophys. Acta, 1997, 1318, 202-216; (d) J. Hendriks, A. Warne, U. Gohlke, T. Haltia, C. Ludovici, M. Lübben and M. Saraste, Biochemistry, 1998, 37, 13102-13109; (e) E. Pinakoulaki, S. Gemeinhardt, M. Saraste and C. Varotsis, J. Biol. Chem., 2002, 277, 5 23407-23413; (f) W. G. Zumft, J. Inorg. Biochem., 2005, 99, 194215; (g) P. Tavares, A. S. Pereira, J. J. G. Moura and I. Moura, J. Inorg. Biochem., 2006, 100, 2087-2100; (h) T. Hino, Y. Matsumoto, S. Nagano, H. Sugimoto, Y. Fukumori, T. Murata, S. Iwata and Y. Shiro, Science, 2010, 330, 1666-1670. (i) N. Xu, J. Yi and G. B. Richter-Addo, Inorg. Chem., 2010, 49, 6253-6266; (j) M. P. Schopfer, J. Wang and K. D. Karlin, Inorg. Chem., 2010, 49, 62676282.

7 F. Bottomely, Acc. Chem. Res., 1978, 11, 158-163.

8 (a) H.-C. Böttcher, M. Graf, K. Mereiter and K. Kirchner, 15 Organometallics, 2004, 23, 1269-1273; (b) T. Mayer, P. Mayer and H.-C. Böttcher, J. Organomet. Chem., 2012, 700, 41-47. 